\title{
Effect of Processing Conditions on Calcium Content, Firmness, and Color of Papaya in Syrup
}

\author{
Nancy Lovera, ${ }^{1}$ Laura Ramallo, ${ }^{2}$ and Viviana Salvadori ${ }^{1,3}$ \\ ${ }^{1}$ CIDCA, CCT LA Plata CONICET, FCE, Universidad Nacional de La Plata, B1900AAJ La Plata, Argentina \\ ${ }^{2}$ FCEQyN, Universidad Nacional de Misiones, AR-N3300LQH Posadas, Argentina \\ ${ }^{3}$ Departamento de Ingeniería Química, FI, UNLP, B1900AAJ La Plata, Argentina
}

Correspondence should be addressed to Laura Ramallo; lram@fceqyn.unam.edu.ar

Received 18 December 2013; Revised 23 May 2014; Accepted 26 May 2014; Published 16 June 2014

Academic Editor: Kit Keith L. Yam

Copyright (C) 2014 Nancy Lovera et al. This is an open access article distributed under the Creative Commons Attribution License, which permits unrestricted use, distribution, and reproduction in any medium, provided the original work is properly cited.

\begin{abstract}
Calcium impregnation is used as a pretreatment in the processing of papaya in syrup. The effect of process temperature (30 and $45^{\circ} \mathrm{C}$ ), calcium source (calcium gluconate and calcium lactate), calcium concentration ( 0.5 and $\left.1.5 \% \mathrm{w} / \mathrm{w}\right)$, and $\mathrm{pH}(4.2$ and 6$)$ were studied. The mineral source affected significantly the calcium uptake and the fruit firmness, and therefore, the product quality maximum content of calcium in the fruit was 240 and $72 \mathrm{mg} / 100 \mathrm{~g}$ fresh fruit in $8 \mathrm{~h}$ of treatment with calcium lactate and calcium gluconate, respectively. Greater firmness was observed in samples impregnated with calcium lactate. Impregnation treatments did not affect the surface color of fruit. Finally, the effect of cooking in sucrose syrup on product quality attributes (calcium retention, firmness, and color) was analyzed. Cooking in syrup had a positive effect on tissue firmness, despite the decrease of calcium content. During cooking in syrup, calcium content of treated fruit decreased between $9 \%$ and $37 \%$. However, the calcium content of fruit in syrup was up to 6 times higher than in fresh fruit. Moreover, the cooking stage had a strong influence on color parameters, leading to a processed product darker than fresh fruit.
\end{abstract}

\section{Introduction}

Papaya (Carica papaya L.) is a fruit native from Central America, widely grown in the subtropical and tropical regions of South America. This fruit can be an important source of carotenes, vitamin $\mathrm{C}$, and $\mathrm{Mg}[1,2]$.

In Argentina, the papaya is mainly marketed as fresh fruit, fruit in syrup, and jam. The papaya in syrup consumed in South America has singular mechanical characteristics: firm surface and soft inner of fruit tissue. Usually, this effect is achieved through successive stages of osmotic dehydration prior to boiling in sucrose syrup.

In this sense, the positive effect of calcium on mechanical properties of different fruits has been widely studied. Calcium is related to vegetable tissue firmness because of its interactions with pectin of cell wall $[3,4]$; in general, calcium uptake increases the firmness of plant tissue [5].

Normally, treatment with calcium solutions is applied before other fruit processings. Thus, the effect of the spraying with calcium solutions on texture and sensory attributes of frozen raspberries and blackberries was studied [6]; similarly a positive correlation between calcium content and hardness of baby carrots by effect of soaking in aqueous calcium chloride solutions was reported [7]. Positive results of calcium impregnation in osmotic dehydration have been observed in different fruits such as papayas [8], mangoes [9], and apples slices [10]. The effect of pretreatment with calcium hydroxide on the calcium uptake and the compression resistance of papaya bits in syrup were investigated [11]. Response surface methodology was used to assess the effects of temperature, concentration, and time on calcium uptake of papaya pieces when calcium hydroxide, calcium gluconate, and calcium lactate were used in soaking treatments [12].

Therefore, this calcium effect on structure and firmness of plant tissue could be applied in the elaboration of papaya in syrup with improved physical characteristics.

On the other hand, salts of divalent cations such as calcium are characterized by bitter and salty tastes. Comparing the taste properties of some calcium salts, it was found that calcium gluconate, calcium glycerophosphate, 
and calcium lactate had lower salty and bitter responses than calcium chloride [13]. Also, calcium lactate is a good alternative to calcium chloride because it does not impart bitterness or off-flavours associated with other calcium salts [14]. Furthermore, calcium lactate, gluconate, and citrate were chosen to enrich cooked sausages because of their solubility, which makes them appropriate for incorporation into foods [15].

Besides, in the last years, many efforts have been done in the development of functional foods, defined as those foods that may provide a health benefit beyond the traditional nutrients it contains. The development of functional foods from several fruits, enriched with probiotics or minerals (calcium and zinc), applying atmospheric or vacuum impregnation, has been thoroughly investigated [16]. The calcium contribution of a food depends on the content and the bioavailability of calcium. The techniques utilized to measure calcium absorption in humans have a lot of methodological difficulties. A study performed in rats reported that apple matrix impregnated with calcium lactate/gluconate is an appropriate vehicle to provide easily absorbable calcium, with apparent absorption of $86.8 \%$, with respect to calcium carbonate absorption [16].

No research records of a relationship between calcium gain and mechanical properties of papaya when calcium lactate or gluconate is used in the soaking treatment are found. In consequence, the aim of this study was to assess the effect of different calcium impregnating treatments on calcium content and mechanical properties of papaya pieces, as pretreatment in the manufacture of papaya in syrup. Evolution of these variables during $8 \mathrm{~h}$ of dipping in calcium solution was analyzed. The operating variables of impregnating treatments in isotonic solutions of calcium gluconate and lactate were calcium concentration, temperature, and $\mathrm{pH}$. Also, the effect of cooking in sucrose syrup on product quality was assessed.

\section{Materials and Methods}

The steps followed the preparation of papaya in syrup were (i) fruit preparation, (ii) impregnation treatment with calcium, and (iii) cooking in sucrose syrup.

2.1. Fruit Preparation. Fresh "Formosa" Papayas (Carica papaya L.) were purchased at a local market in Misiones (Argentine) and stored at $8 \pm 1^{\circ} \mathrm{C}$ until they were used (less than 5 days). In order to ensure reproducible results, similar fresh fruits of commercial ripeness grade 5 (76-100\% of yellow surface [17]) with masses of $1.50 \pm 0.35 \mathrm{~kg}, a_{w}$ values of $0.989 \pm 0.03$, and soluble solids content of $10-12.5^{\circ}$ Brix were selected. Before the experiments, the fruits were carefully washed with distilled water and peeled manually and sample cylinders (10.5 $\pm 0.5 \mathrm{~mm}$ height, $30 \pm 1 \mathrm{~mm}$ diameter $)$ were cut with a stainless steel cork borer from the inner fruit pulp.

2.2. Impregnation Treatments. Different aqueous solutions containing calcium gluconate or calcium lactate (food grade, Parafarm, Argentine) were prepared. These conditions are detailed in Table 1. Calcium salts were selected as mineral source because of their relative high solubility at room temperature; also they provide no additional taste to the fruit [18]. In each case, enough amount of sucrose was added to calcium solution, in order to obtain calcium solutions with the same soluble solids content that papaya fruit have (Example: $10.8 \mathrm{~g}$ of sucrose was added to $100 \mathrm{~mL}$ of aqueous solution with $0.5 \% \mathrm{w} / \mathrm{w}$ calcium gluconate when the soluble solids content in the fruit was $10^{\circ}$ Brix). Principal carbohydrates found in the papaya fruit are glucose, sucrose, and fructose, but during papaya ripening there is an increase in sucrose content; sugar being the most abundant in ripe fruit [19].

Thereby, solutions were isotonic with respect to soluble solids content to avoid osmotic dehydration [20].

Trials T1-T8 were done in order to evaluate the effect of temperature and calcium concentration in impregnation assays with calcium gluconate and calcium lactate independently. In these trials, $\mathrm{pH}$ of impregnating solutions was not fixed, only was measured (Table 1).

Experiments T9-T12 were done in order to evaluate the effect of solution $\mathrm{pH}$ in calcium intake (Table 1). Calcium gluconate $2.2 \% \mathrm{w} / \mathrm{w}$ or calcium lactate $1.5 \% \mathrm{w} / \mathrm{w}$ was added to isotonic solutions of distilled water and sucrose, with temperature fixed in $45^{\circ} \mathrm{C}$. In these experiments, concentrations of the calcium salts were selected in order to ensure the same mineral content in the impregnating solution. Solution $\mathrm{pH}$ was fixed using buffer solutions $\left(\mathrm{KH}_{2} \mathrm{PO}_{2}-\mathrm{K}_{2} \mathrm{HPO}_{2}\right.$ $0.02 \mathrm{M})$.

In each impregnation assay, 34 cylinders obtained from the same fruit were placed in a plastic beaker (volume $2 \mathrm{~L}$ ) and covered with the impregnating solution, using a $4 / 1$ mass ratio of impregnating solution to fruit. Containers were maintained at constant temperature and agitation (150 rpm) using a thermostatized shaker (Barnstead Lab Line MaxQ 4000, Barnstead International, Dubuque, USA), during $8 \mathrm{~h}$ for trials T1 to T8, and for $4 \mathrm{~h}$ for trials T9 to T12.

Every 2 hours, eight samples were randomly removed from the solution and washed three times with distilled water, using for each wash a 3/1 ratio volume of water to fruit, in order to remove free calcium attached to the sample surface. These 8 cylinders were divided in two sets; 2 samples were used to quantify calcium content and the other 6 to evaluate color and mechanical properties. Besides, mechanical properties, color and calcium content of fresh fruits, determined in every assay, were used as a reference.

In treatments $\mathrm{T} 1$ to $\mathrm{T} 8$, two samples were kept in the impregnating solution for 24 hours to measure calcium content.

With the purpose of analyzing the effect of dipping in isotonic sucrose solutions per se on mass loss and mechanical characteristics, a comparative analysis was performed between two assays at $45^{\circ} \mathrm{C}$ for $8 \mathrm{~h}$, using isotonic sucrose solution (without calcium) and isotonic sucrose solution with added $1.5 \%(\mathrm{w} / \mathrm{w})$ calcium lactate (with calcium). Mass and mechanical properties of these samples were measured every $2 \mathrm{~h}$. For each treatment, all the samples were extracted from the same fruit to avoid the natural variability among different fruits of the same kind. 
TABLE 1: Experimental conditions used in the calcium impregnation treatments.

\begin{tabular}{|c|c|c|c|c|}
\hline Treatment & Mineral source & Concentration $(\% \mathrm{w} / \mathrm{w})$ & Temperature $\left({ }^{\circ} \mathrm{C}\right)$ & $\mathrm{pH}$ \\
\hline $\mathrm{T} 1$ & Calcium gluconate & 0.5 & 30 & 6.2 \\
\hline $\mathrm{T} 2^{*}$ & Calcium gluconate & 1.5 & 30 & 6.2 \\
\hline $\mathrm{T} 3$ & Calcium gluconate & 0.5 & 45 & 6.2 \\
\hline $\mathrm{T} 4$ & Calcium gluconate & 1.5 & 45 & 6.2 \\
\hline T5 & Calcium lactate & 0.5 & 30 & 8.4 \\
\hline $\mathrm{T}^{*}$ & Calcium lactate & 1.5 & 30 & 8.4 \\
\hline T7 & Calcium lactate & 0.5 & 45 & 8.4 \\
\hline $\mathrm{T}^{*}$ & Calcium lactate & 1.5 & 45 & 8.4 \\
\hline $\mathrm{T}^{*}$ & Calcium gluconate & 2.2 & 45 & 4.2 \\
\hline $\mathrm{T} 10^{*}$ & Calcium gluconate & 2.2 & 45 & 6.0 \\
\hline $\mathrm{T}_{1}{ }^{*}$ & Calcium lactate & 1.5 & 45 & 4.2 \\
\hline $\mathrm{T} 12^{*}$ & Calcium lactate & 1.5 & 45 & 6.0 \\
\hline
\end{tabular}

${ }^{*}$ Selected experiences to evaluate the effect of cooking in syrup on fruit calcium content and tissue firmness.

2.3. Cooking Fruit in Sucrose Syrup. In order to evaluate the effect of cooking in syrup on papaya calcium content and tissue firmness some impregnation treatment conditions (Table 1) were selected.

Fruit samples with $4 \mathrm{~h}$ of impregnation treatment were placed into a stainless steel vessel containing the sucrose solution $\left(60^{\circ}\right.$ Brix), $5 / 1$ mass ratio of syrup to fruit, at boiling temperature for $1 \mathrm{~h}$.

2.4. Moisture and Soluble Solids Content. Moisture content of fresh fruit was measured according to AOAC method 925.09 [21].

Soluble solids content, expressed as ${ }^{\circ}$ Brix, was measured using a Hanna HI96801 digital refractometer (precision \pm 0.01 ).

At last, mass loss, WL, was calculated as the percentage difference between initial and final sample weight (wet basis), $W_{i}$ and $W_{f}$, respectively, according to

$$
\mathrm{WL}(\%)=\frac{W_{i}-W_{f}}{W_{i}} \times 100 .
$$

2.5. Calcium Content. The calcium content was measured by atomic absorption spectrophotometry. A mass of approximately $2 \mathrm{~g}$ of previously dried sample was crushed and calcined in a muffle furnace at $550^{\circ} \mathrm{C}$. Ashes were then dissolved in HCL 2N, filtrated, and diluted with deionized water up to a volume of $25 \mathrm{~mL}$. Calcium content of these solutions was evaluated using a Perkin Elmer 3110 atomic absorption spectrometer (PerkinElmer Inc., USA), under the following conditions: wavelength $422.7 \mathrm{~nm}$, slit width $0.7 \mathrm{~nm}$, and fuel/oxidant ratio 2.5/4.5. Calcium content is expressed as $\mathrm{mg} \mathrm{g}^{-1} \mathrm{ff}\left(\mathrm{mg} / \mathrm{g}\right.$ fresh fruit) and as calcium gain, $\Delta C=C-C_{o}$, where $C_{o}$ and $C$ are the calcium content in fresh and treated fruit, respectively. Measurements were done in duplicate.

2.6. Mechanical Properties. Firmness of fresh and processed fruit was evaluated using a TA.XT2i Texture Analyser (Stable Micro Systems, Surrey, UK). A puncture test was performed, using a $3 \mathrm{~mm}$ circular section stainless steel probe (probe $\mathrm{P} / 3$ ), test speed of $0.5 \mathrm{~mm} / \mathrm{s}$, and load cell of $5 \mathrm{~kg}$. Tests were performed on the flat side of each cylinder. Reported values correspond to the average of 6 measurements. Fruit firmness was defined as the maximum registered force $\left(F_{\max }\right)$ to penetrate the sample by $30 \%$ of its initial height $[22,23]$.

2.7. Color. Surface color was measured using a CR-300 colorimeter (Minolta, Japan), and chromaticity parameters $a^{*}$ and $b^{*}$ and luminosity $L^{*}$ values were recorder.

From those values, Hue angle and Chroma parameters were calculated through (2). Results presented in this work correspond to the average of 8 measurements.

Consider

$$
\begin{gathered}
\text { Hue angle }=\tan ^{-1}\left(\frac{b^{*}}{a^{*}}\right) \quad a^{*} \neq 0 \\
\text { Chroma }=\left(a^{* 2}+b^{* 2}\right)^{1 / 2} .
\end{gathered}
$$

2.8. Statistical Analysis. Statistical analyses were performed using STATGRAPHICS software [24]. The results analysis of treatments with calcium gluconate and calcium lactate was performed independently.

Differences between treatments with calcium gluconate (T1-T4) or calcium lactate (T5-T6), for each dipping time, were tested by analysis of variance (ANOVA). When ANOVA showed statistical differences $(P<0.05)$, pairwise comparisons of means were performed using multiple range Fisher's tests (LSD).

The $\mathrm{pH}$ effect on calcium uptake and firmness of fruit was evaluated through trials T9-T12, by ANOVA and LSD tests. Dipping time was used in order only to visualize the evolution of the variables along immersion process, but it was not considered as a factor in the ANOVA. 


\section{Results and Discussion}

\subsection{Calcium Uptake}

3.1.1. Effect of Concentration and Temperature of Impregnation Treatments. With the aim of obtaining a processed product with high nutritional quality grade, only ripe fruits were selected. In papaya fruits, ripeness is associated with high carotene content [25].

In fresh fruit (ff), average calcium content was $18.6 \pm$ $4.1 \mathrm{mg} / 100 \mathrm{~g}$ ff and increased considerably during impregnation, reaching 70 and $240 \mathrm{mg} / 100 \mathrm{~g} \mathrm{ff}$ in samples treated at $45^{\circ} \mathrm{C}$ for $8 \mathrm{~h}$ with $1.5 \% \mathrm{w} / \mathrm{w}$ of calcium gluconate and lactate, respectively. Similar results were obtained in the study on calcium impregnation of apple cylinders immersed in isotonic glucose solution containing a mixture of calcium lactate and calcium gluconate [18].

Figure 1(a) shows the increase in calcium content in samples treated with calcium gluconate solutions. Results showed that neither the concentration nor temperature significantly affect calcium uptake (Table 2) when calcium gluconate is used as mineral source. Likewise, in papaya samples impregnated with calcium lactate solutions, the calcium uptake was significantly affected by both salt concentration and temperature $(P<0.05)$, (Figure $1(\mathrm{~b})$ and Table 2). Besides, a positive interaction between temperature and salt concentration was observed. In all treatments, the fruit calcium content increased with soaking time.

Treatments with calcium gluconate for $24 \mathrm{~h}$ soaking (Figure 1(a) and Table 2) show that only the papaya calcium content with $\mathrm{T} 1$ treatment was significantly lower $(P<0.05)$ than calcium content values of papaya samples with other treatments. On the contrary, calcium impregnation in papaya samples was notoriously affected by concentration and temperature when calcium lactate was used as mineral source, in treatments of $24 \mathrm{~h}$ soaking (Figure $1(\mathrm{~b})$ and Table 2 ). So, the highest calcium uptake was that obtained through treatment T8 $\left(1.5 \% \mathrm{w} / \mathrm{w}\right.$ and $\left.45^{\circ} \mathrm{C}\right)$. Others researchers reported that calcium incorporation and texture of papaya were affected by temperature, calcium chloride concentration, and treatment time [26].

3.1.2. Effect of the Impregnating Solution $p H$. Based on the fact that calcium gluconate concentration and temperature of impregnation solution has no significant effect on papaya calcium uptake, the results of treatments T9, T10 $(2.2 \%, \mathrm{w} / \mathrm{w})$, and T2 $(1.5 \%, w / w)$ can be compared. From these results, it can be inferred that calcium uptake and $\mathrm{pH}$ of calcium gluconate solution do not present any correlation.

Since the assays were performed with different raw fruits, calcium contents of fresh fruit are reported in Table 3. The high variability in the calcium content of fruit tissue was also observed in a study about the development of a functional (fortified with calcium) apple matrix [18].

At $\mathrm{pH}$ 6, the results obtained with calcium gluconate and calcium lactate, at the same temperature, were very close (Table 3). However, the calcium content of papaya samples impregnated with calcium lactate at $\mathrm{pH} 8.4$ was higher than the calcium content of samples treated at $\mathrm{pH} 6$, but there were
TABLE 2: Multiple comparison results of calcium content in each time between treatments with calcium gluconate (T1-T4) or calcium lactate (T5-T8).

\begin{tabular}{lcccccc}
\hline Treatment & $0 \mathrm{~h}$ & $2 \mathrm{~h}$ & $4 \mathrm{~h}$ & $6 \mathrm{~h}$ & $8 \mathrm{~h}$ & $24 \mathrm{~h}$ \\
\hline T1 & $\mathrm{a}$ & $\mathrm{a}$ & $\mathrm{a}$ & $\mathrm{a}$ & $\mathrm{a}$ & $\mathrm{a}$ \\
T2 & $\mathrm{a}$ & $\mathrm{b}$ & $\mathrm{a}$ & $\mathrm{ab}$ & $\mathrm{a}$ & $\mathrm{bc}$ \\
T3 & $\mathrm{a}$ & $\mathrm{a}$ & $\mathrm{a}$ & $\mathrm{ab}$ & $\mathrm{a}$ & $\mathrm{b}$ \\
T4 & $\mathrm{a}$ & $\mathrm{ab}$ & $\mathrm{a}$ & $\mathrm{b}$ & $\mathrm{a}$ & $\mathrm{c}$ \\
\hline T5 & $\mathrm{a}$ & $\mathrm{a}$ & $\mathrm{a}$ & $\mathrm{a}$ & $\mathrm{a}$ & $\mathrm{a}$ \\
T6 & $\mathrm{ab}$ & $\mathrm{ab}$ & $\mathrm{b}$ & $\mathrm{b}$ & $\mathrm{b}$ & $\mathrm{b}$ \\
T7 & $\mathrm{b}$ & $\mathrm{b}$ & $\mathrm{b}$ & $\mathrm{b}$ & $\mathrm{b}$ & $\mathrm{b}$ \\
T8 & $\mathrm{b}$ & $\mathrm{c}$ & $\mathrm{c}$ & $\mathrm{c}$ & $\mathrm{c}$ & $\mathrm{c}$ \\
\hline
\end{tabular}

${ }^{*}$ Different letters in the same column indicate significant differences according to LSD test $(P<0.05)$.

no differences with calcium content of samples treated at $\mathrm{pH}$ 4.2 , when the same concentration and temperature was used (T8, T11, and T12 treatments). These results show that the effect of $\mathrm{pH}$ on the papaya calcium uptake was not clear, but the highest calcium concentration in the vegetable matrix was achieved by the impregnation treatment with calcium lactate at $\mathrm{pH} 4.2$.

3.1.3. Effect of Cooking in Sucrose Syrup. To elaborate papaya in syrup, impregnation treatment conditions were selected based on calcium uptake values (upper and middle) of treated fruits. Calcium content of papaya fresh fruit, treated fruit ( $4 \mathrm{~h}$ of calcium impregnation treatment), and papaya in syrup (treated fruit and then cooked in sucrose syrup during 1h) is shown in Table 3. Fruit calcium content increased during impregnation treatments, but the subsequent cooking process had a negative effect regarding calcium retention. During cooking in syrup, calcium content of treated fruit decreased between $9 \%$ and $37 \%$. However, the calcium content of fruit in syrup was up to 6 times higher than in fresh fruit. The calcium loss in treated fruit could occur due to a fraction of calcium that is not bound chemically to the vegetable matrix and diffuses to the sucrose solution during the cooking process.

The calcium source (lactate or gluconate) had no influence on the fraction of calcium loss after cooking in syrup. However, final products with the highest calcium content were obtained from pretreated fruit samples which contained the highest calcium levels. This fact shows the importance of ensuring the appropriate conditions for the calcium impregnation step.

The highest tissue calcium content obtained after cooking in sucrose solution was $80.6 \pm 23.6 \mathrm{mg} / 100 \mathrm{~g}$ fresh fruit (Table 2, T11 treatment). Considering $200 \mathrm{~g}$ of fruit (a portion), the calcium content is equivalent to $20 \%$ of the recommended daily intake (RDI) for adults. According to the Argentine Food Code [27] fortified foods must contribute from $20 \%$ to $100 \%$ of RDI (1000 mg Ca/day) to be considered as such. Hence, papaya in syrup, impregnated with calcium lactate, could be labeled as fortified food. 


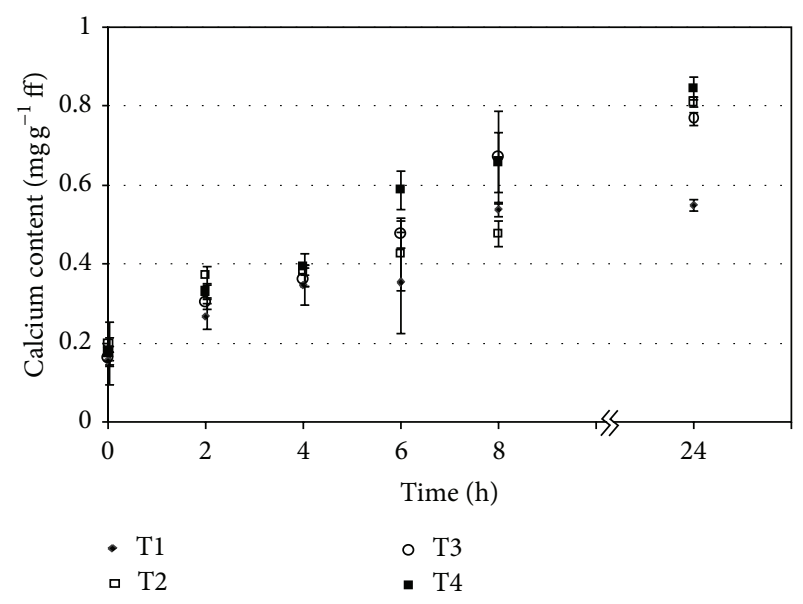

(a)

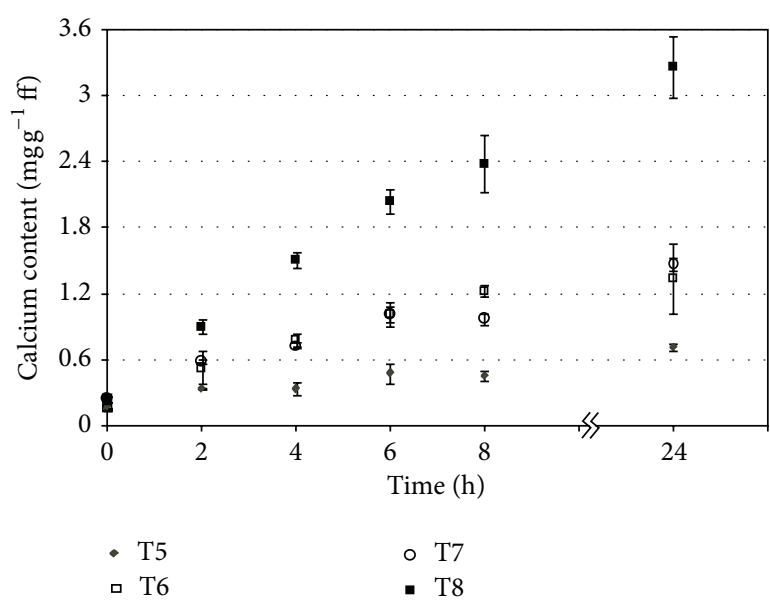

(b)

FIGURE 1: Calcium content in papaya fruit during impregnation treatments with (a) calcium gluconate (T1-T4) and (b) calcium lactate (T5T8).

TABLE 3: Calcium content and relative firmness of fresh papaya, treated papaya and cooked papaya in syrup.

\begin{tabular}{|c|c|c|c|c|c|}
\hline \multirow{2}{*}{ Treatment } & \multicolumn{3}{|c|}{$\mathrm{C} \times 10^{2}\left(\mathrm{mg} \mathrm{g}^{-1} \mathrm{ff}\right)$} & \multicolumn{2}{|c|}{$F_{\max } / F_{\max }^{0}$} \\
\hline & Fresh fruit & Treated fruit & Cooked & Treated fruit & Cooked \\
\hline $\mathrm{T} 2$ & $23.6 \pm 5.7^{\mathrm{a}}$ & $40.9 \pm 10.6^{\mathrm{a}}$ & $38.0 \pm 6.8^{\mathrm{a}}$ & $1.57 \pm 0.38^{\mathrm{a}}$ & $1.76 \pm 0.47^{\mathrm{a}}$ \\
\hline T9 & $12.9 \pm 1.0^{\mathrm{b}}$ & $59.4 \pm 6.8^{\mathrm{a}}$ & $36.7 \pm 3.5^{\mathrm{a}}$ & $1.54 \pm 0.78^{\mathrm{a}}$ & $1.73 \pm 0.55^{\mathrm{a}}$ \\
\hline $\mathrm{T} 10$ & $12.9 \pm 1.0^{\mathrm{b}}$ & $71.4 \pm 10.6^{\mathrm{a}}$ & $56.8 \pm 0.9^{\mathrm{b}}$ & $2.24 \pm 0.64^{\mathrm{b}}$ & $5.09 \pm 1.33^{\mathrm{b}}$ \\
\hline $\mathrm{T} 8$ & $14.8 \pm 3.3^{\mathrm{a}}$ & $102.2 \pm 8.1^{\mathrm{a}}$ & $70.8 \pm 2.6^{\mathrm{a}}$ & $5.45 \pm 1.29^{\mathrm{a}}$ & $8.65 \pm 1.16^{\mathrm{a}}$ \\
\hline T11 & $12.9 \pm 1.0^{\mathrm{a}}$ & $116.1 \pm 1.8^{\mathrm{a}}$ & $80.6 \pm 23.6^{\mathrm{a}}$ & $3.92 \pm 1.10^{\mathrm{b}}$ & $5.91 \pm 1.04^{\mathrm{b}}$ \\
\hline $\mathrm{T} 12$ & $12.9 \pm 1.0^{\mathrm{a}}$ & $78.3 \pm 0.2^{\mathrm{b}}$ & $48.6 \pm 4.1^{\mathrm{a}}$ & $4.93 \pm 1.16^{\mathrm{ab}}$ & $1.78 \pm 0.33^{\mathrm{c}}$ \\
\hline
\end{tabular}

${ }^{*}$ Treated fruit $=$ fruit samples with $4 \mathrm{~h}$ of impregnation treatment.

${ }^{*}$ Results are expressed as means \pm standard deviation.

${ }^{*}$ Values with different letters indicate significant differences $(P<0.05)$ between treatments with calcium gluconate $(\mathrm{T} 2, \mathrm{~T} 9$ and T10) or calcium lactate $(\mathrm{T} 8$, T11 and T12).

3.2. Mechanical Properties. Changes in firmness of papaya samples after different impregnation assays are shown in Figure 2, where $F_{\max }^{0}$ and $F_{\max }$ are the maximum force of fresh fruit and treated fruit, respectively. The texture parameter is reported as relative force $F_{\max } / F_{\max }^{0}$, dimensionless, in order to avoid the variability of tissue firmness found in different fresh papaya fruits, which were in the range $0.25-0.83 \mathrm{~N}$. The variability of those values was mainly due to the variability between fruits, since the coefficient of variation for this texture parameter was always less than $17 \%$ within the same fruit. A considerable variability in mechanical properties of raw materials was also observed in studies with apples, guavas, and pumpkins, respectively [28-30].

Fruit firmness was significantly affected $(P<0.05)$ by mineral source, calcium lactate, or gluconate (Figure 2 ). Thus, higher values of calcium content and tissue firmness were measured when calcium lactate was used.

Increasing treatment temperature from 30 to $45^{\circ} \mathrm{C}$ had no significant effect on papaya firmness $(P>0.05)$ when calcium gluconate was applied. Moreover, the temperature increase had a positive effect on fruit tissue firmness when calcium lactate solution concentration at $0.5 \%$ was used, but it did not affect tissue firmness at 1.5\% w/w (Figure 2(b)). Tissue firmness increased with impregnating solution concentration at $30^{\circ} \mathrm{C}$ (T5 and T6) but not at $45^{\circ} \mathrm{C}$ (T7 and T8).

In conclusion, an increase in fruit tissue firmness due to calcium impregnation was observed in all treatments. Significant linear relationship $(R \geq 0.85)$ between firmness and calcium uptake was only registered for treatments with calcium lactate (T5, T6, and T7) and not for treatments with calcium gluconate $(R<0.80)$, except for the T4 assay $(R=$ 0.98).

It was also observed that relative firmness $F_{\max } / F_{\max }^{0}$ increased from 1 to 5 when the calcium gain $\Delta C$ increased from 0 to $70 \mathrm{mg} / 100 \mathrm{~g} \mathrm{ff}$, but the firmness of the fruit remained at values $F_{\max } / F_{\max }^{0} \approx 5$ when $\Delta C$ values increased from 70 to $200 \mathrm{mg} / 100 \mathrm{~g}$ ff.

It is known that binding of pectin, present in the fruit with $\mathrm{Ca}$ ions, provides a more rigid structure in the middle lamella of the cell wall [31]. The continuous increase in the calcium content without affecting fruit firmness could be due to molecular diffusion of the mineral in the solid food without formation of calcium-pectin bonds in plant tissue, a mechanism that is favored by higher temperatures and by increased calcium concentrations in the impregnating solution. 


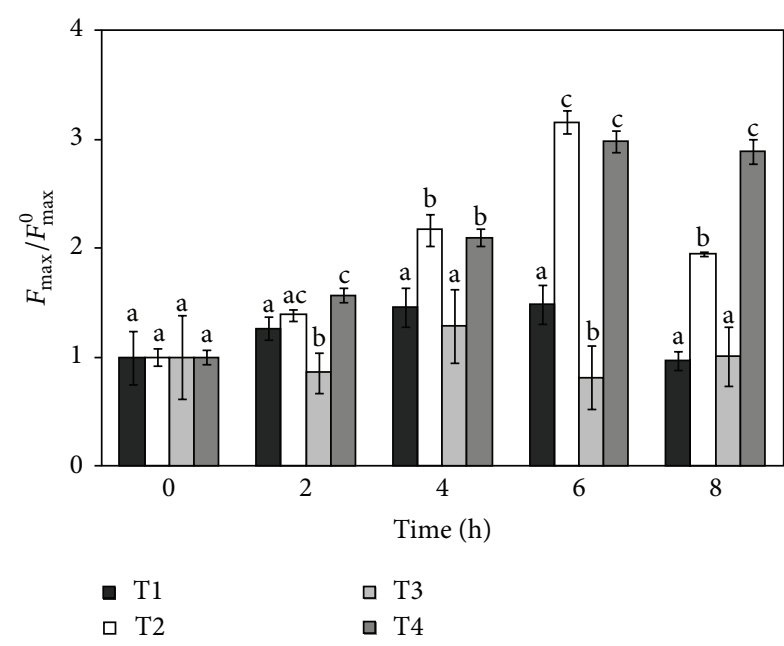

(a)

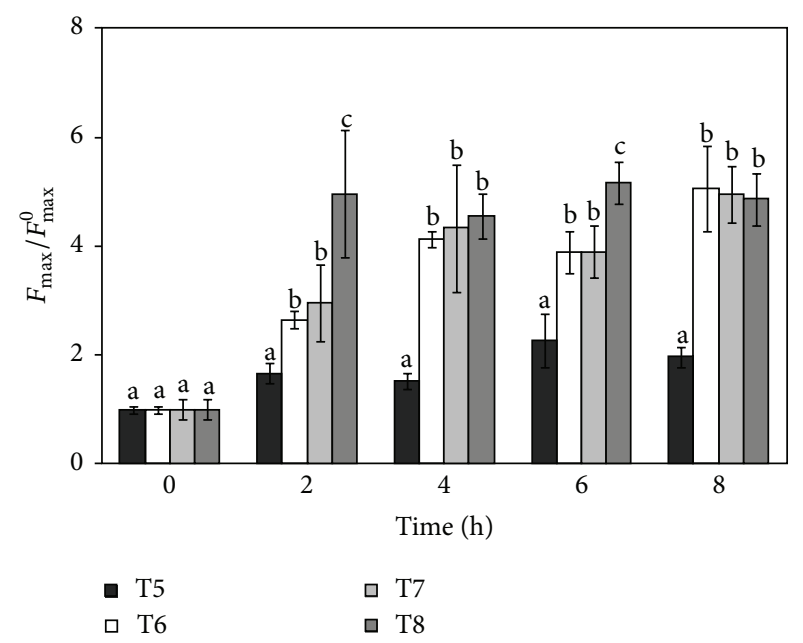

(b)

FIGURE 2: Firmness of papaya fruit during impregnation treatments with (a) calcium gluconate (treatments T1-T4) and (b) calcium lactate (treatments T5-T8). Different letters indicate significant differences $(P<0.05)$ between treatments at each time.

Values of mass loss (1) and relative firmness $\left(F_{\max } / F_{\max }^{0}\right)$ of papaya cylinders were compared between two soaking treatments in isotonic sucrose solution at $45^{\circ} \mathrm{C}$, with and without addition of calcium lactate. Addition of calcium lactate $(1.5 \% \mathrm{w} / \mathrm{w})$ to the isotonic solution increased fruit firmness and limited mass losses during soaking (Table 4). After a treatment of 8 hours in the solution without calcium, fruit tissue becomes less resistant to puncture $\left(F_{\max }\right.$ diminished to $82 \%$ of the initial value), which confirms that the increment in $F_{\max }$ values can be attributed to calcium increment in the fruit tissue ( $8 \mathrm{~h}$ in solution with calcium, $F_{\max }$ increased up to a $300 \%$ of the value for fresh fruit). In agreement with our results, it was found that values of fracture stress for osmotically dehydrated papaya with calcium chloride as additive were significantly higher than those for other dehydration treatments [8].

The loss of mass observed in treatment without calcium could be due to the detachment of small solid particles as a result of the medium's agitation and, in smaller proportion, to loss by lixiviation of components other than sucrose. The absorption of calcium by the tissue seems to provide a higher resistance to friction, avoiding rupture and mass loss. Fruit moisture content (g water/100 g matter) changed only $2 \%$ $(90.2$ to $88.5 \mathrm{~g} / 100 \mathrm{~g}$ ) during $8 \mathrm{~h}$ of soaking in isotonic sucrose solution without calcium addition, which would indicate that mass loss was not due to a dehydration process.

Just as calcium uptake, fruit firmness was positively affected by $\mathrm{pH}$ of impregnation medium (Figure 3 ). There were significant differences $(P<0.05)$ between $F_{\max } / F_{\max }^{0}$ values of treatments with calcium lactate at same calcium concentration and different $\mathrm{pH}$ values.

McFeeters and Fleming studied the effect of $\mathrm{pH}$ (range 2.5-9) on the firmness of cucumber pickles with the addition of calcium chloride in the brine. They found that the firmness of cucumber tissues tended to increase as $\mathrm{pH}$ increased; maximum values of firmness were registered at $\mathrm{pH}$ between 4 and $8[32]$.
TABLE 4: Firmness $\left(F_{\max } / F_{\max }^{0}\right)$ and mass loss $(\Delta W)$ of papaya cylinders during dipping in isotonic sucrose solution at $45^{\circ} \mathrm{C}$, with and without calcium addition.

\begin{tabular}{lcccc}
\hline \multirow{2}{*}{ Time (h) } & \multicolumn{2}{c}{$F_{\max } / F_{\max }^{0}$} & \multicolumn{2}{c}{$\Delta W \%$} \\
& With Ca & Without Ca & With Ca & Without Ca \\
\hline 0 & $1.00 \pm 0.37$ & $1.00 \pm 0.06$ & 0 & 0 \\
2 & $4.00 \pm 1.76$ & $0.96 \pm 0.02$ & 0.68 & 4.54 \\
4 & $3.63 \pm 1.09$ & $0.69 \pm 0.05$ & 2.63 & 8.43 \\
6 & $3.64 \pm 0.33$ & $0.86 \pm 0.08$ & 2.30 & 12.16 \\
8 & $3.02 \pm 0.56$ & $0.82 \pm 0.04$ & 0.12 & 16.18 \\
\hline
\end{tabular}

Note: $F_{\max } / F_{\max }^{0}=$ relative firmness.

Results are expressed as means \pm standard deviation.

Mechanical properties of the treated and cooked fruit were determined in order to compare their parameters with those of the fresh papaya. Firmness values $F_{\max } / F_{\max }^{0}$ of papaya samples are shown in Table 3. It can be observed that cooking in syrup had positive effect on tissue firmness. So, cooked fruit was firmer (>rupture force, $F_{\max }$ ) than treated papaya. Therefore, cooked fruit was drastically firmer than fresh fruit. Also, a severe decrease in the slope of the forcedeformation curve (data not shown) was caused by cooking in syrup. These changes in mechanical properties of the fruit would suggest that papaya in syrup is a more firm and elastic product than fresh fruit.

3.3. Color. There was no significant influence $(P>0.05)$ of impregnation time on any of the three analyzed color parameters L, Chroma, and Hue (data not shown). These parameters were not significantly affected by conditions of the impregnation treatment $(P>0.05)$, indicating that color purity and brightness of the fresh fruit remained unchanged during calcium impregnation. 


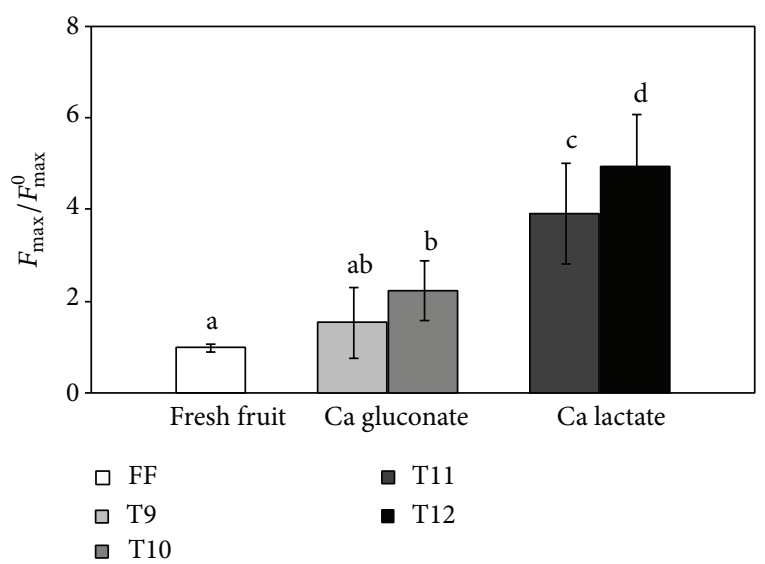

FIgURE 3: Firmness of fresh papaya fruit (FF), treated fruit with calcium gluconate solutions (T9; T10) and with calcium lactate solutions (T11, T12), at pHs fixed at 4.2 and 6. Different letters indicate significant difference $(P<0.05)$.

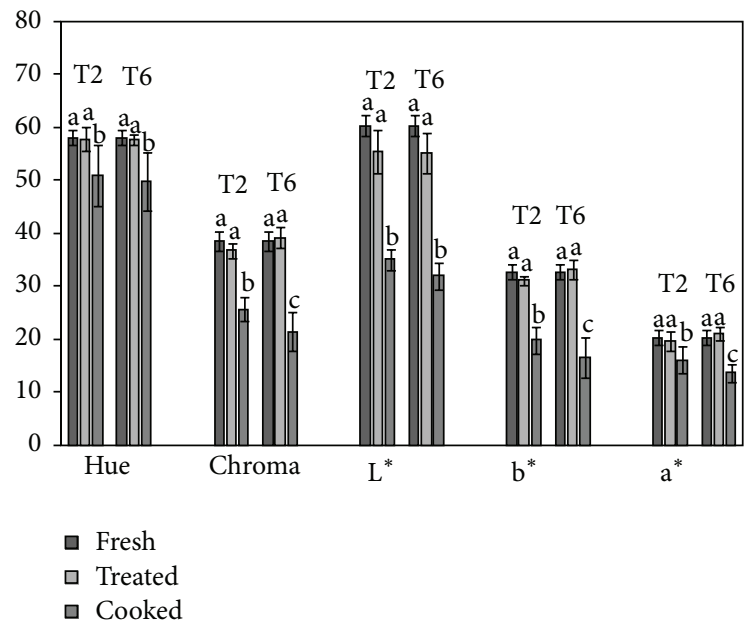

FIGURE 4: Color parameters of fresh fruit, treated fruit, and fruit cooked in syrup, in two different conditions of processing (T2 and T6). Different letters indicate significant difference in each color parameter according to LSD test $(P<0.05)$.

On the other hand, the cooking step had a strong influence on color parameters. To illustrate this fact, color parameters values are shown in Figure 4. Two assays, with the same operative impregnation conditions, but using calcium gluconate (T2) and calcium lactate (T6), were selected. Similar results were found with other samples and different impregnation conditions. Cooking in syrup led to a darker tone of papaya (lower $L^{*}$ and Chroma), for all treatment conditions, whereas the Hue angle values were slightly reduced (decrease in yellowness) by the effect of cooking. When the CIEL $a b$ parameters $b^{*}$ and $a^{*}$ are analyzed independently, it was found that both were significantly $(P<0.05)$ lower in cooked fruit than in fresh fruit and for treated samples.

\section{Conclusions}

Experimental results presented in this work show that it was possible to obtain processed papaya in syrup with nutritive and mechanical properties better than in the fresh fruit.

The calcium level reached in the impregnation step depends mainly on the mineral source. Calcium content in treated fruit with calcium lactate was three times higher than for treated fruit with calcium gluconate. Neither the concentration nor temperature affects calcium gain when calcium gluconate is used as mineral source. Instead, when calcium lactate is used, the level of calcium uptake depends on both concentration and temperature. Cooking in syrup presented a negative impact regarding calcium retention, with respect to the impregnation process: the calcium content of treated fruit decreased between $9 \%$ and 37\%. However, the calcium content of the fruit in syrup was up to 6 times higher than that of the fresh fruit.

Mineral source also affects significantly $(P<0.05)$ the fruit firmness $\left(F_{\max } / F_{\max }^{0}\right)$, greater firmness is observed in samples impregnated with calcium lactate. Besides, the step of cooking in syrup had a noticeable effect on tissue firmness, so that the cooked fruit was more firm and elastic than the fresh fruit. In addition, there was no negative impact of impregnation treatments on the surface color. The cooking in syrup led to processed fruits being darker than the fresh ones.

\section{Conflict of Interests}

The authors declare that there is no conflict of interests regarding the publication of this paper.

\section{Acknowledgments}

This work was financially supported by the Consejo Nacional de Investigaciones Científicas y Técnicas (CONICET) and Universidad Nacional de La Plata (UNLP)-Proyecto 111140, from Argentine.

\section{References}

[1] M. M. Wall, "Ascorbic acid, vitamin A, and mineral composition of banana (Musa sp.) and papaya (Carica papaya) cultivars grown in Hawaii," Journal of Food Composition and Analysis, vol. 19, no. 5, pp. 434-445, 2006.

[2] U. G. Chandrika, E. R. Jansz, S. M. D. N. Wickramasinghe, and N. D. Warnasuriya, "Carotenoids in yellow- and red-fleshed papaya (Carica papaya L)," Journal of the Science of Food and Agriculture, vol. 83, no. 12, pp. 1279-1282, 2003.

[3] C. Brett and K. Waldron, Physiology and Biochemistry of Plant Cell Walls, Chapman and Hall, London, UK, 1990.

[4] M. L. Gras, D. Vidal, N. Betoret, A. Chiralt, and P. Fito, "Calcium fortification of vegetables by vacuum impregnation: interactions with cellular matrix," Journal of Food Engineering, vol. 56, no. 2-3, pp. 279-284, 2003.

[5] G. T. Grant, E. R. Morris, D. A. Rees, P. J. C. Smith, and D. Thom, "Biological interactions between polysaccharides and divalent 
cations: the egg-box model," FEBS Letters, vol. 32, no. 1, pp. 195198, 1973.

[6] M. B. Sousa, W. Canet, M. D. Alvarez, and C. Fernández, "Effect of processing on the texture and sensory attributes of raspberry (cv. Heritage) and blackberry (cv. Thornfree)," Journal of Food Engineering, vol. 78, no. 1, pp. 9-21, 2007.

[7] N. K. Rastogi, L. T. Nguyen, and V. M. Balasubramaniam, "Effect of pretreatments on carrot texture after thermal and pressureassisted thermal processing," Journal of Food Engineering, vol. 88, no. 4, pp. 541-547, 2008.

[8] A. C. C. Rodrigues, R. L. Cunha, and M. D. Hubinger, "Rheological properties and colour evaluation of papaya during osmotic dehydration processing," Journal of Food Engineering, vol. 59, no. 2-3, pp. 129-135, 2003.

[9] J. D. Torres, P. Talens, I. Escriche, and A. Chiralt, "Influence of process conditions on mechanical properties of osmotically dehydrated mango," Journal of Food Engineering, vol. 74, no. 2, pp. 240-246, 2006.

[10] M. L. Castelló, M. Igual, P. J. Fito, and A. Chiralt, "Influence of osmotic dehydration on texture, respiration and microbial stability of apple slices (Var. Granny Smith)," Journal of Food Engineering, vol. 91, no. 1, pp. 1-9, 2009.

[11] L. A. Ramallo and T. Liotta, "Efecto de las condiciones de elaboración en la incorporación de calcio y la firmeza del mamón (Carica papaya L.) en almíbar," Revista de Ciencia y Tecnología, vol. 16, pp. 59-64, 2012.

[12] L. Müller and L. A. Ramallo, "Efectividad de diferentes sales en relación a la incorporación de calcio en mamón," in Proceedings of the 13th Congress of Food Science and Technology (CYTAL '11), Buenos Aires, Argentina, 2011.

[13] H. T. Lawless, F. Rapacki, J. Horne, and A. Hayes, "The taste of calcium and magnesium salts and anionic modifications," Food Quality and Preference, vol. 14, no. 4, pp. 319-325, 2003.

[14] I. Luna-Guzmán and D. M. Barrett, "Comparison of calcium chloride and calcium lactate effectiveness in maintaining shelf stability and quality of fresh-cut cantaloupes," Postharvest Biology and Technology, vol. 19, no. 1, pp. 61-72, 2000.

[15] E. Cáceres, M. L. García, and M. D. Selgas, "Design of a new cooked meat sausage enriched with calcium," Meat Science, vol. 73, no. 2, pp. 368-377, 2006.

[16] S. M. Alzamora, D. Salvatori, M. S. Tapia, A. López-Malo, J. Welti-Chanes, and P. Fito, "Novel functional foods from vegetable matrices impregnated with biologically active compounds," Journal of Food Engineering, vol. 67, no. 1-2, pp. 205214, 2005.

[17] T. Pereira, P. S. G. de Almeida, I. G. de Azevedo et al., "Gas diffusion in "Golden" papaya fruit at different maturity stages," Postharvest Biology and Technology, vol. 54, no. 3, pp. 123-130, 2009.

[18] S. V. Anino, D. M. Salvatori, and S. M. Alzamora, "Changes in calcium level and mechanical properties of apple tissue due to impregnation with calcium salts," Food Research International, vol. 39, no. 2, pp. 154-164, 2006.

[19] J. G. de Oliveira and A. P. Vitória, "Papaya: Nutritional and pharmacological characterization, and quality loss due to physiological disorders. An overview," Food Research International, vol. 44, no. 5, pp. 1306-1313, 2011.

[20] M. González-Fésler, D. Salvatori, P. Gómez, and S. M. Alzamora, "Convective air drying of apples as affected by blanching and calcium impregnation," Journal of Food Engineering, vol. 87, no. 3, pp. 323-332, 2008.
[21] AOAC, Official Methods of Analysis of the Association of Official Analytical Chemists, Edited by K. Helrich, AOAC, Washington, DC, USA, 5th edition, 1995.

[22] T. S. Vu, C. Smout, D. N. Sila, B. LyNguyen, A. M. L. Van Loey, and M. E. G. Hendrickx, "Effect of preheating on thermal degradation kinetics of carrot texture," Innovative Food Science and Emerging Technologies, vol. 5, no. 1, pp. 37-44, 2004.

[23] R. M. Schweiggert, C. B. Steingass, E. Mora, P. Esquivel, and R. Carle, "Carotenogenesis and physico-chemical characteristics during maturation of red fleshed papaya fruit (Carica papaya L.)," Food Research International, vol. 44, no. 5, pp. 1373-1380, 2011.

[24] Statgraphics, Centurion XV. Statpoint Technologies, Inc, Warrenton, Va, USA, 2009.

[25] M. P. Cano, M. G. Ancos, and M. Monreal, "Carotenoid pigments and colour of hermaphrodite and female papaya fruits (Carica papaya L.) cv Sunrise during post-harvest ripening," Journal of the Science of Food and Agriculture, vol. 71, pp. 351358, 1999.

[26] I. Perez-Lopez, J. Welti-Chanes, A. Lopez-Malo, E. Palou, and A. Ibarz, "Calcium incorporation in papaya by low temperature blanching," in Proceedings of the IFT Annual Meeting Book of Abstracts, Anaheim, Calif, USA, 2002.

[27] Argentine Food Code, 2012, http://www.anmat.gov.ar/alimentos/normativas_alimentos_caa.asp.

[28] P. P. Lewicki and A. Lukaszuk, "Effect of osmotic dewatering on rheological properties of apple subjected to convective drying," Journal of Food Engineering, vol. 45, no. 3, pp. 119-126, 2000.

[29] L. M. Pereira, A. C. C. Rodrigues, C. I. G. L. Sarantópoulos, V. C. A. Junqueira, R. L. Cunha, and M. D. Hubinger, "Influence of modified atmosphere packaging and osmotic dehydration on the quality maintenance of minimally processed guavas," Journal of Food Science, vol. 69, no. 4, pp. 172-177, 2004.

[30] L. Mayor, R. L. Cunha, and A. M. Sereno, "Relation between mechanical properties and structural changes during osmotic dehydration of pumpkin," Food Research International, vol. 40, no. 4, pp. 448-460, 2007.

[31] L. G. Bartolome and J. E. Hoff, "Firming of potatoes: biochemical effects of preheating," Journal of Agricultural and Food Chemistry, vol. 20, no. 2, pp. 266-270, 1972.

[32] R. F. McFeeters and H. P. Fleming, "pH Effect on calcium inhibition of softening of cucumber mesocarp tissue," Journal of Food Science, vol. 56, pp. 730-732, 1991. 

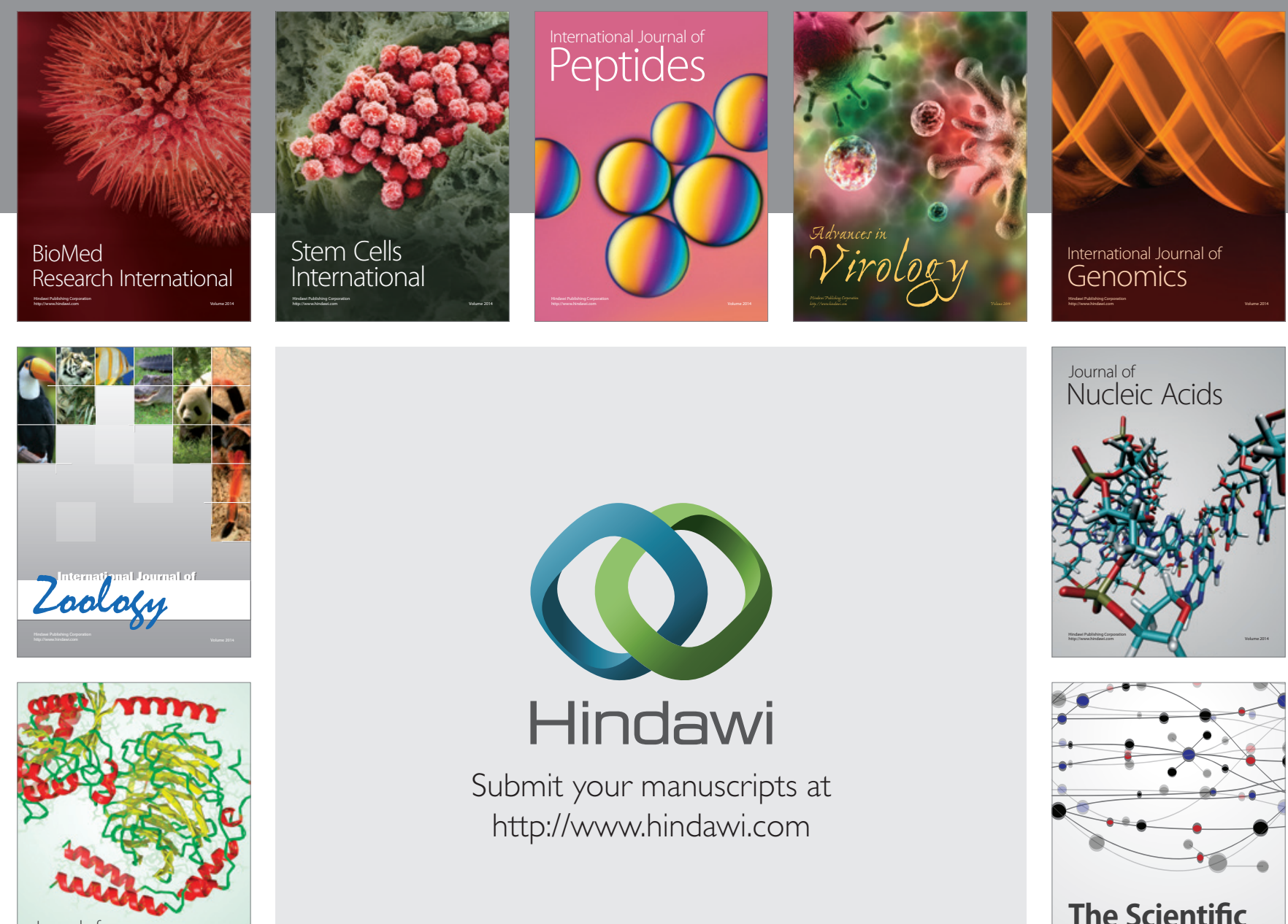

Submit your manuscripts at

http://www.hindawi.com

Journal of
Signal Transduction
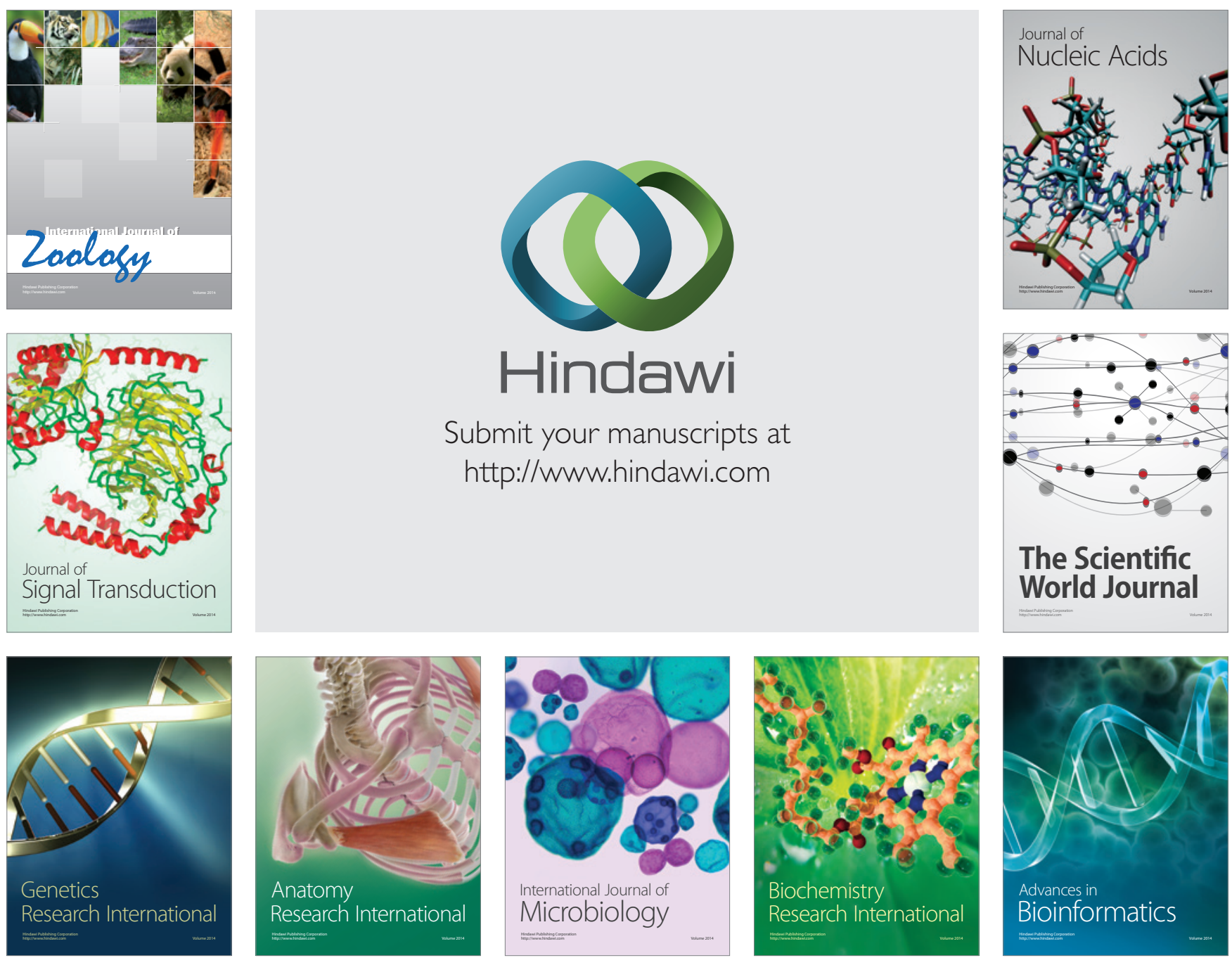

The Scientific World Journal
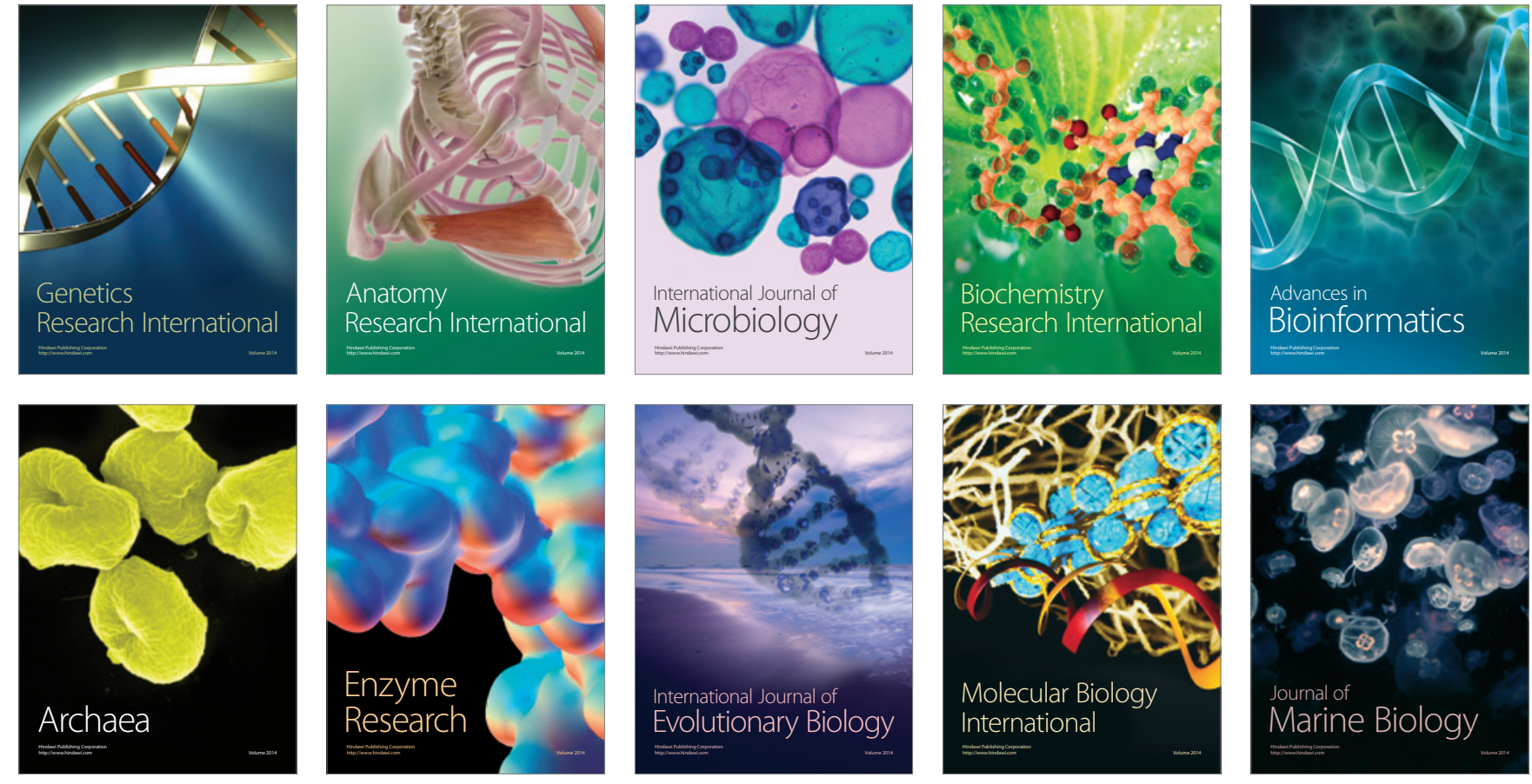